\title{
PRINCIPLE OF THE AFFIRMATIVE DUTY OF PUBLIC ADMINISTRATION IN THE FACE OF COVID-19 PANDEMICS - IN RELATION TO THE ACT ON THE STATE OF NATURAL DISASTER OF 18 APRIL 2002
}

\author{
IWONA NIŻNIK DOBOSZ
}

\begin{abstract}
Principle of the Affirmative Duty of Public Administration in the Face of COVID-19 Pandemics - in Relation to the Act on the State of Natural Disaster of 18 April 2002 In view of the obligation of affirmative duty of public administration in the timely way, the author of this paper is verifying the thesis that failing to meet this obligation, in Poland, during the COVID-19 epidemic, the Council of Ministers did not introduce the state of natural disaster regulated by the Constitution and the natural disaster management act.
\end{abstract}

Keywords: State of natural disaster (legal status); natural disaster (factual circumstances); COVID-19 epidemic (factual circumstances); state of epidemic (legal status); state of epidemic risk (legal status); Constitution of the Republic of Poland

DOI: $10.14712 / 23366478.2021 .40$

\section{INTRODUCTION - A NOTION AND GENESIS OF A PRINCIPLE OF AFFIRMATIVE DUTY FOR PUBLIC ADMINISTRATION IN DUE TIME}

At the start, it should be noted that the administrative and legal principle of an affirmative duty for public administration originates in a principle of the rule of law and legality of public administration activities, as well as in the absolutely binding character of the norms of administrative law and in the specific character of task norms addressed to public administration.

Pursuant to Article 7 of the Constitution of the Republic of Poland of 2 April 1997, the public authority bodies act on the basis and within the limits of law. It means that an affirmative or negative duty as well as sufferance from the side of public authorities, including public administration bodies, should have a legal basis (principle of legality), and acting pursuant to this legal basis, should be compliant with the legal order (rule of law).

The absolutely binding character of administrative law norms, or more broadly perceived as a public law norm, means that the norm of this law is absolutely binding in its content (without a possibility of modification) both as an entity applying this norm, such as a competent body of public administration, as well as its other addressees, who usually are the entities which do not belong to the public administration system. Obvi- 
ously, the same valour is attached to administrative law norms, addressed only to public administration bodies. On the other hand, the task norms contained in administrative law place a priority of public administration bodies to certain projects to be performed, continuously existing in time, which are characterized by the fact that they are not of a one-off character but are continuous, permanent, repeatable in time. ${ }^{1}$ In order to perform public tasks, the public administration is endowed by the legislature by acts of parliament with competences ${ }^{2}$ which make up its so-called forms of activity, ${ }^{3}$ which, respectively, allow public administration for an appropriate "activation" both in a sphere of formation of executive regulations to the acts of law, and further in a sphere of the application of law and in a sphere of its enforcement. When teaching administrative law, it is emphasized that competences of public administration bodies constitute both its authorization as well as its duty. This is derived from the fact that administrative law norms are focused on the public administration introducing changes in the surrounding reality. It occurs both as a result of the legal activity of public administration, meant to cause legal impact as well as in a form of material and technical activities foremostly focused on evoking factual impact (in a sphere of facts).

In consequence of the above findings, it can be stated that the principle of affirmative duty of public administration means that in a case when the factual circumstances occur, provided for in a hypothesis of a legal norm, public administration has an obligation (duty) to undertake an activity contained in a disposition of this norm. It refers to either making, exercising, applying, as well as enforcing the law. ${ }^{4}$ Also, here it should be emphasized that the discussed principle is not indifferent in relation to a period of time during which a body of public administration is supposed exercise its competences. Therefore, this principle should be defined as a principle of affirmative duty for public administration in the due time. Currently in administrative law, apart from the rule of law and legality, emphasis is placed on the normal functioning of public administration in a timely manner, and its inactivity and excessive length of its activities are subject to appropriate appeals to the regional administrative courts. ${ }^{5}$ One should distinguish the inactivity and excessive length of proceeding by public administration bodies, which are of pejorative character, from the silence of a public administration body, which has positive valour and which the law connects with material legal effects, which will be discussed below.

1 Regarding the task norms see FILIPEK, J. (ed.). Elementy strukturalne norm prawa administracyjnego. Zeszyty Naukowe UJ, DCXXVII. Prace Prawnicze, No. 99. Warszawa - Kraków: Państwowe Wydawnictwo Naukowe - Uniwersytet Jagielloński, 1982, pp. 63-69.

2 Regarding competences see BOĆ, J. (ed.). Prawo administracyjne. Wrocław: Kolonia Limited, 2004, p. 143.

3 Regarding the forms of activities see OCHENDOWSKI, E. Prawo Administracyjne: czesść ogólna. Toruń: Towarzystwo Naukowe Organizacji i Kierownictwa "Dom Organizatora", 2018, pp. 189-229. See ZACHARKO, I. - MATAN, A. - ŁASZCZYCA, G. (eds.). Ewolucja prawnych form administracji publicznej: księga jubileuszowa z okazji 60. rocznicy urodzin Profesora Ernesta Knosali. Warszawa: Oficyna a Wolters Kluwer business, 2008.

4 Regarding the principle of affirmative duty see FILIPEK, J. Prawo administracyjne: instytucje ogólne. Część I. Kraków: Towarzystwo Autorów i Wydawców Prac Naukowych Universitas, 1995, p. 24.

5 See Art. $3 \S 2$ section 8-9 of the Act on proceedings before administrative courts of 30 August 2002 Dz.U. - Journal of Laws - 2019, 2325, consolidated text. 
It should be also pointed out that the discussed principle, in its own characteristic way, "breaks through", determines in a defined real factual circumstance the so-called discretionality and facultativeness of the forms of public administration activities, because it obliges a public administration body - regarding discretionality - to take up an appropriate, content-related activity within the framework of the available freedom of decision-making. In case of the facultativeness of the forms of activity, respectively, it obliges a public administration body to choose such facultative forms of activity, which are the most adequate and appropriate in relation to given factual circumstances.

The presented way of thinking on the competences of administrative bodies is based on a statement that the competences of a public administrative body means both the right and the obligation to take advantage of these competences, and additionally something which has not been mentioned up to this point - the principle of cooperation in public administration, as well as a principle of the civil society - they embed these competences in a configuration of complementarity and synergy.

Therefore, it is practically meaningless whether in the law currently in force the competences of public administration bodies are formed as authorizing or obliging norms, since an authorization in a specific reality, in factual circumstances - what is actually provided for in a hypothesis of a legal norm - becomes a duty.

Here it should be emphasized, that the discretionality and facultativeness of public administration actions $\mathrm{s}^{6}$ are more significant in those situations, when they appear in regulations which do not contain hypotheses. Then, a public administration body possessing such competences should verify whether the existing factual status in a given reality is legally relevant pursuant to the axiology (values and principles) of the legal system and - having obtained a positive verification justified by those principles, institutions of law in a scope of interpretation and argumentation should exercise these competences. In the described system, particular importance is attached to the interpretation of law - in which a response is sought to its attitude to an existing factual circumstance which are not described directly in a hypothesis of the norm, which does not mean that it is indifferent to law and exercise of public administration competences.

From the foregoing, it can be concluded that the factual state, which is not indifferent, relevant for the norms of administrative law, appears in a hypothesis of a competence norm, and also emerges from the entirety of legal regulations which are connected in reference to their contents, function, and purpose to a competence of a public administration body, embedded in a norm which does not have a hypothesis. ${ }^{7}$

The affirmative duty principle is also not subject to derogation in case of institutional silence from the side of an administrative body, which the act of law connects a legal

6 Regarding the range of freedom of the public administration activities see BŁAŚ, A. - BOĆ, J. JEŻEWSKI, J. - BOĆ, J. (eds.). Administracja publiczna. Wrocław: Kolonia Limited, 2003, pp. 230-241. Regarding the administrative recognition see FILIPEK, J. Prawo administracyjne: instytucje ogólne. Część II. Kraków: Kantor Wydawnictwo Zakamycze, 2001, pp.73-85.

7 Compare, inter alia, Art. 17 of the Governmental Administration Audit Act of 15 July 2011 Dz.U. - Journal of Laws - 2020.224 uniform text, pursuant to which "[the] head of an auditing entity may appoint a team of auditors to conduct the audit", as well as Art. 18 section 1 of this Act "[the] head of the auditing entity may include as auditors the employees of organizational bodies and entities, subordinated or controlled by the head of the auditing entity, who have specialist knowledge". 
effect with. ${ }^{8}$ It should be emphasized that if a public administration body waives its right to object to a defined request brought in by an individual or to accept this request solely due to the expiration of the time to perform acts in law, should be unconditionally preceded by internal procedures within that public administration's body, which should verify a request prior to taking advantage of an institution's silence. ${ }^{9}$ Otherwise, the silence of a public administration body will be based on a pejorative lack of activity arising from ineffectiveness in its operations.

This feature of administrative law, that places in front of public administrative bodies a requirement of its continuous verification with factual circumstances existing in reality, should be looked at from the perspectives of the domestic law as well as the European and international law.

\section{LEGAL BASES OF PUBLIC ADMINISTRATION ACTIVITIES IN VIEW OF SARS-COV-2 EPIDEMIC}

It is obvious that the global epidemic crisis caused by SARS-CoV-2 virus outbreak forced executive authority bodies of particular states to take up appropriate measures connected with counteracting its impact. In this case, the subject of these actions was and still is a special value such as human life and health, as well as public health, respectively, as well as the human capacity of existence and self-fulfilment, plus the capacity of the structures of a state and territorial self-government to act. The author of this paper aims at describing how the Polish public administration undertook these actions from a perspective of the principle of the rule of law and a principle of obligation of the public administration to act in the due time.

Here it should be stated that due to the characteristics and effects of epidemic, the Polish public administration faced a problem involving not only the organization of measures preventing the SARS-CoV-2 virus from spreading, on account of protection of life and health, but also securing the operations of state institutions as a result of consequences of the epidemic, including public administration, so therefore with time also the problem of public and social security appeared, caused by the effects of epidemic. ${ }^{10}$

From the beginning of its existence, the epidemic crisis raised a problem of legal bases of public authorities' activities during the epidemic. ${ }^{11}$ It was a verification of preparation by the Polish legislature of legal bases regarding these circumstances and the adherence of public administrations activities to law. In the case of Poland,

8 See Art. 122a-122h of the Act on 14 June 1960. Administrative procedures code, Dz.U. - Journal of Laws 2021. 735, consolidated text.

9 See DOBOSZ, P. Milczenie i bezczynność w prawie administracyjnym. Kraków: Wydawnictwo Uniwersytetu Jagiellońskiego, 2011, pp. 83-90.

10 See Act of 2 March 2020 on special solutions connected with prevention, counteraction and management of COVID-19, other infectious diseases and related crisis situations, Dz.U. - Journal of Laws - 2020.1840, consolidated text. Pursuant to its Art. 2 the provisions of the act applied to infection and infectious diseases caused by the SARS-CoV-2 virus, hereinafter referred to as "COVID-19".

11 TULEJA, P. Ustawa o stanie klęski żywiołowej czy ustawa o zapobieganiu oraz zwalczaniu zakażeń i chorób zakaźnych u ludzi (polemika). In: Monitor Konstytucyjny: Konstytucja, Państwo, Prawo [online]. 10.4.2020 [cit. 2021-08-07]. Available at: http://monitorkonstytucyjny.eu/archiwa/13404. 
a principle of affirmative duty of public administration, discussed in this paper in view of the SARS-CoV-2 epidemic "collided with" a problem of the Council of Ministers failing to introduce a state of natural disaster by way of regulations of the Council of Ministers, and this happened despite the existence in the legal system of appropriate Constitutional foundations, as well as of the Act on the State of Natural Disaster of 18 April 2002. ${ }^{12}$ This act determines the mode of introduction and abolishment of the state of natural disaster, as well as the principle of activity for public authority bodies as well as a scope of restrictions placed on human and civic freedoms and rights in the duration of natural disaster. ${ }^{13}$ In view of this act of law, the epidemic undisputedly constitutes a kind of a natural disaster. ${ }^{14}$ Further, in this place and time, it is not necessary to argue more broadly that Poland was actually experiencing a state of an epidemiological threat and the COVID-19 epidemic. ${ }^{15}$ As an effect of this legislative negligence on the side of the Polish Council of Ministers, we dealt with restrictions of constitutional rights and freedoms by way of regulations issued by the Council of Ministers and other public administration bodies (Minister of Health and a voivode, an official in charge of an administrative district) within the so-called ordinary constitutional measures scheduled for ordinary, typical situations, i.e. on a basis of the revised Act of 05 December 2008 on the Prevention and Combating Infectious Diseases in Humans. This act did not have and does not have anything to do with the Act on the State of Natural Disaster, possessing the qualified valour as an effect of its contents and constitutional foundations in Chapter XI, since it did not, pursuant to the Constitution - refer to its institution, including a legal notion such as a state of natural disaster, perceived as a special legal regime. Such legislative activity leading to conferment in the public administration act of blanket law-making authorizations to issue regulations regarding statutorily provided for potential restrictions of constitutional freedoms and rights and at the same time deviating from a constitutional notion of natural disaster with all of its constitutional restrictions - is not compliant with the Polish Constitution. ${ }^{16}$ In other words, the provisions of an ordinary act of law which was not issued in reference to the constitutional legal notion of a natural disaster, were expanded by the Polish legislature by extraordinary, exceptional measures, in a form of extraordinary law-making competences of public administration bodies. However, the Polish legislature did not preserve the values

12 Regarding this subject see FLORCZAK-WĄTOR, M. Niekonstytucyjność ograniczeń praw i wolności jednostki wprowadzonych w związku z epidemią COVID-19 jako przesłanka odpowiedzialności odszkodowawczej państwa. Państwo i Prawo. 2020, No. 12, p. 6.

13 Dz.U. - Journal of Laws - 2017.1897 consolidated text.

14 See Art. 3(1)(1-2) of the Act on the state of natural disaster. A notion of a state of natural disaster includes - apart from a notion of technical breakdown - also a notion of a natural emergency. A notion of a natural disaster includes "mass occurrence of infectious diseases".

15 See, inter alia, the regulation of the Minister of Health of 12 March 2020 regarding the publication of the state of epidemic threat in the territory of the Republic of Poland, Dz.U. - Journal of Laws, item 433; of 20 March 2020 regarding the cancelling of the state of epidemic threat in the territory of the Republic of Poland, Dz.U. - Journal of Laws, item 490.

16 Only during the state of emergency can the rights and freedoms (if any) guaranteed by the Constitution be suspended, because then Art. 31 of the Constitution of the Republic of Poland is not a model of legality for law-making activity, only Art. 228 section 5 of the Constitution of the Republic of Poland, which is quoted in the main text. See NIŻNIK-MUCHA, A. Zakaz naruszania istoty konstytucyjnych wolności i praw w Konstytucji RP. Warszawa: Wydawnictwo Sejmowe, Kancelaria Sejmu, 2014, pp. 155-158. 
and reasons which the Constitution connects extraordinary states, including natural disasters. In the ordinary lawmaker's assessment - erroneous in the author's opinion - it was not necessary to link the epidemic or the epidemiological threat (as factual circumstances) in the Act of 05 December 2008 on the Prevention and Combating Infection and Infectious Diseases in People, with the constitutional legal status of a natural disaster (so therefore a special legal regime introduced in case of a natural disaster). However, it did not prevent the legislature from introducing "a state of epidemic" and the legal "state of an epidemiological threat" and include in it the law-making competences for a public administration, which it may only have in the legal constitutional state of natural disaster. What is more, the legislature in this controversial act increased a catalogue of restrictions placed on constitutional rights and freedoms, adding a law-making competence to public administration bodies (to the Council of Ministers, a voivode, and the Minister of Health) in a form of a regulation introducing restrictions in the organization of public events and other public assemblies. It had become a convenient excuse when introducing this restriction by way of a regulation, due to the expanded interpretation of this law, which was unconstitutional anyway, to interfere - by inter alia - the Police in the constitutional freedom of assembly with complete omission of axiology of the Constitution connected with this notion. ${ }^{17}$

Here it should be explained that the Constitution of the Republic of Poland includes Article 31(3) to regulate standard, ordinary restrictions of rights and freedoms, pursuant to which: "Restrictions in the scope of exercising constitutional freedoms and rights may be established only in the act of law and only when it is necessary in a democratic state for its safety or public order or to protect the environment, health and public morality, or freedoms and rights of other persons. These restrictions cannot encroach on the merits of freedoms and rights."

The quoted provision undisputedly states that the restrictions listed therein constitute the statutory material (a subject of regulation of the act of law), and their introduction in an ordinary act of law is limited by the abovementioned constitutional grounds and the so-called test of proportionality ${ }^{18}$ as well as a prohibition of encroachment on the merits of freedoms and rights. In this respect, i.e. - the restriction in the scope of taking advantage of constitutional freedoms without the so-called ordinary/common constitutional measures - does the Constitution provide for issuance by the public administration bodies (executive bodies) of regulations regarding restriction of the rights and freedoms in a scope indicated in the act of law.

However, what should be strongly emphasized, in situations of particular hazardous conditions, if the ordinary constitutional measures are not sufficient (meaning here the norms which can be reconstructed without a reference to the contents of Chapter 11 of the Constitution titled: "States of Exception"), pursuant to Article 228 of the Constitution, the appropriate state of exception may be introduced: such as martial law, a state of emergency, or a state of natural disaster. A state of emergency may be introduced only pursuant to such an act which is referred to in the Constitution, and what is im-

17 See FLORCZAK-WĄTOR, $c . d .$, p. 18.

18 See NIŻNIK-MUCHA, c. d., pp. 159-180. 
portant - in a form of a regulation of the Council of Ministers, which additionally has to be communicated to the public.

It is important to mention here that the activities of public authority bodies and a scope to which human and civic freedoms and rights can be restricted during particular states of exception are specified in reference to an enumerative catalogue of such restrictions contained in the Constitution by an act of law, which in the Polish legal order is the Act on the State of Natural Disaster of 18 April 2002. This act, pursuant to the Constitution, may define the bases, scope, and method of compensation for material losses arising from the temporary restriction of human and civil rights during a state of emergency. The most important issues connected with extraordinary measures are regulated, first and foremost, by the Constitution. This is the Constitution which gives a direction to relevant executive acts referring to particular states of exception.

Article 232 of the Constitution directly regulates the legal status of a state of natural disaster (an exceptional legal regime) deciding that in order to prevent the effects of natural disasters or technical breakdowns displaying the hallmarks of a natural disaster and to remedy them, the Council of Ministers may introduce, for a defined period of time, no longer than 30 days, a state of natural disaster in a part or on the entire territory of the state. This state of emergency may be prolonged with the consent of the Sejm (Parliament). The Constitution states that the activities undertaken as a result of the introduction of a state of exception must correspond to the anticipated level of threat and should strive to achieve the quickest possible restoration of the normal functioning of the state. This norm contained in Article 228(5) of the Constitution is essential for a constitutionality assessment in cases of extraordinary solutions and in the event a state of natural disaster constitutes an alternative for Article 31(3) as a model of constitutionality, which applies to ordinary constitutional measures.

Pursuant to Article 233(1) of the Constitution, the act defining a scope of restrictions of human and civil rights and freedoms during martial law and a state of emergency cannot restrict the freedoms and rights defined in Article 30 (human dignity), Article 34 and Article 36 (citizenship), Article 38 (protection of life), Article 39, Article 40 and Article 41(4) (humanitarian treatment), Article 42 (the ascription of criminal liability), Article 45 (access to a court), Article 47 (personal rights), Article 53 (conscience and religion), Article 63 (petitions), and Article 48 and Article 72 (family and child). It is unacceptable to restrict human and civil freedoms and rights solely due to the race, sex, language, religious affiliation of the lack thereof, social origin, birth, and property (Article 233(2)). At the same time, pursuant to Article 233(3) of the Constitution, the act defining a scope of restrictions of human and civil rights and freedoms during a state of natural disaster may restrict freedoms and rights defined in Article 22 (freedom of business activity), Article 41(1)(3) and (5) (personal freedom), Article 50 (inviolability of the home), Article 52(1) (freedom of moving around and staying in the territory of the Republic of Poland), Article 59(3)3 (right to strike), Article 64 (right of ownership), Article 65(1) (freedom of work), Article 66(1) (right to safe and hygienic working conditions), and Article 66(2) (right to time off).

From the foregoing it can be concluded that the introduction of a state of natural disaster in the Republic of Poland, in accordance with the constitutional solutions, con- 
sists of two stages. At the first stage, an ordinary legislature introduced to the legal order the act on the state of natural disaster and next, in performance of this act and norms of the Constitution, the Council of Ministers may, by way of regulation, introduce the legal state of natural disaster at its own initiative or at an initiative of a competent voivode, if in factual, real circumstances the grounds for a declaration of natural disaster occurs. In this regulation the Council of Ministers will specify the reasons, date of introduction, the territorial scope, and the duration of a state of natural disaster as well as, what is extremely important, the scope allowed by the Act on the State of Natural Disaster, the kinds of necessary restrictions of human and civil rights and freedoms. So therefore, in a state of natural disaster, this is an act of law which provides for potential restrictions of human and civil freedoms and rights, however, the restriction of those rights is activated only at the moment of issuance and publication of a regulation on a state of natural disaster, in which the Council of Ministers selects from the act of law these restrictions, which are appropriate in combating a given natural disaster.

The regulation is published in the Journal of Laws of the Republic of Poland, and moreover it is communicated to the public by a voivode, for example by the placement of posters in public places, and also in a manner which is customary in a given territory.

From the first part of the article, dedicated to the affirmative duty of public administration, it can be derived that at the moment when in factual circumstances the reasons appear for hypotheses of the norm, then the authorizations of public administration bodies, including the Council of Ministers, become its obligations.

As the contents of this article will prove, the Council of Ministers failed to meet this obligation connected with the introduction of a legal status of a natural disaster.

Here it has to be particularly emphasized that a constitutional legal notion of a state of emergency is strongly qualified by the law, and has special valour which are material and formal, since, during a state of exception, the following acts of law cannot be amended: the Constitution, election ordinance to the Sejm, Senate and territorial self-government bodies, the Act on Presidential elections in the Republic of Poland, and the act on states of exception. During the state of exception, and 90 days following its end, a term of office for the Sejm cannot be shortened, a general referendum, the elections to the Sejm, Senate, territorial self-government bodies and the Presidential elections in the Republic of Poland cannot be held, while their terms of office are prolonged, respectively Elections to the territorial self-government bodies are possible only where the state of exception has not been introduced. A state of exception, including specifically a state of natural disaster, is introduced for a defined period of time, not longer than 30 days, in a part or in the entire territory of the state. This status can be prolonged with the consent from the Sejm.

From the foregoing it can be concluded that the constitutional legislature, the Constitution maker, perfectly understands that a legal state of exception is unique and temporary, allowed by the Act the Council of Ministers to have a law-making reaction, treated as a contingency measure and adjusted to factual circumstances, and consisting in restrictions of rights and freedoms within the limits of authorizations contained in the Constitution and the Act on the State of Natural Disaster, in a form of secondary legislation to the act. In this case, in the regulation the types of restrictions of rights and 
freedoms indicated in the act of law are selected. Therefore, in these particular legal and at the same time factual circumstances, the fundamental political issues of the state and its citizens should not be solved, such as the ones defined above. However, it is the introduction of a state of exception which the legislature explicitly links with the payment of appropriate damages for restrictions in a scope of exercising constitutional freedoms and rights. ${ }^{19}$

Here it should be indicated that in view of the COVID-19 epidemic - an ordinary constitutional legislature - despite the existence of constitutional and statutory regulation regarding the legal state of natural disaster and the natural disaster itself (as the factual circumstances), including undisputedly and directly also the epidemic 20 - introduced to the ordinary act of law, i.e. to the Act of 05 December 2008 on the Prevention and Combating Infection and Infectious Diseases in People ${ }^{21}$ in Article 46(a) and (b) ${ }^{22}$ regulations providing for the restriction of rights and freedoms by competent bodies by way of executive provisions. It is unacceptable, without the application of a constitutional institution of introduction of the legal state of natural disaster. For this purpose, the ordinary legislature used the term "state of epidemiological threat" 23 and "state of epidemic", ${ }^{24}$ respectively, and on account for just these notions the legislature statutorily authorized the public administration bodies in a form of blanket authorizations for law-making activity by way of regulations introducing the potential restrictions of constitutional human rights and freedoms of a citizen and other legal entities, what has been provided for in an act of law.

Pursuant to Article 46 of the Act on the Prevention and Combating Infection and Infectious Diseases in People, the state of epidemiological threat or the state of epidemic in the area of a region or its part is announced and revoked by a voivode by way of regulation, on the initiative of a state voivodeship sanitary inspector. If the epidemiological threat or epidemic appears in the territory of more than one voivodeship, the state of epidemiological threat or state of epidemic is announced and revoked, by way of regulation, by the minister of health in cooperation with the minister of public administration

19 Regarding this subject see the Act of 22 November 2002 on compensation of material losses arising from restriction in time of human and civil rights during the state of emergency, Dz.U. - Journal of Laws 233, 1955. See ŁĘTOWSKA, E. Za głupstwa królów płacą ich narody - indemnizacja w czasie zarazy (cz. I). In: konstytucyjny.pl [online]. 12.5.2020 [cit. 2021-08-07]. Available at: https://konstytucyjny.pl/za -glupstwa-krolow-placa-ich-narody-indemnizacja-w-czasie-zarazy-cz-i/.

20 Epidemic is included in a statutory notion of a state of emergency, which is a factual circumstance. A state of emergency is a legal state, a special legal regime introduced on the basis of an act of law by the Council of Ministers in a form or a regulation.

21 Dz.U.2019.1239 consolidated text.

22 These regulations were added by Art. 25 item 4 of the Act of 2 March 2020 on special solutions connected with prevention, counteraction and management of COVID-19, other infectious diseases and related crisis situations, Dz.U. - Journal of Laws - 374.

23 See Art. 2 item 23 of the Act of 5 December 2008 under which the state of epidemic risk - is a legal situation introduced in a given area in connection with a risk of epidemic occurrence, in order to undertake preventive measures specified in the act of law, whereas the epidemic - is the occurrence in a given area of infection or infectious diseases incidences in a number which is clearly higher than in a previous period or the occurrence of infection or infectious diseases so far non-existent (Art. 2(9)).

24 See Art. 2(22) of the Act of 5 December 2008 under which the state of epidemic is a legal situation introduced in a given area in connection with the occurrence of epidemic in order to undertake anti-epidemic and preventive measures specified in the act of law for minimization of the effects of epidemic. 
on the initiative of the Head Sanitary Inspector. Announcing the state of epidemiological threat or the state of epidemic, the Minister of Health or a voivode may impose a duty to undergo protective vaccinations or vaccinations against other infection and infectious diseases, referred to in the act of law. In the above regulations the following can be established: 1) the temporary restriction of a defined method of moving around; 2 ) the temporary restriction or prohibition of trading and using of specified items or food products; 3 ) the temporary restriction of the functioning of specified institutions or workplaces; 4) the prohibition of organizing entertainment and other assemblies; 5) a duty to perform defined sanitary procedures, if they are connected with functioning of specified sanitary procedures, if their performance is connected with functioning of specified manufacturing, service, trading, or other entities; 6) an order to give access to properties, commercial units, premises, and making means of transportation available for anti-epidemic procedures provided for in anti-epidemic plans; 7) a duty to undergo protective vaccinations referred to in section 3 , and groups of persons subject to these vaccinations, a kind of conducted protective vaccines - taking into consideration the ways of spreading the infection and infectious diseases and an epidemic situation in the area on which the state of epidemiological threat or the state of epidemic was announced.

These regulations are immediately published in an appropriate official gazette, pursuant to the regulations on publications of normative acts, they take effect from the date of publication.

A voivode's duty is to inform citizens on their obligations arising from regulations stemming from provisions described above in a way customarily accepted in a given territory.

Further, pursuant to Article 46(a) of the Act on the Prevention and Management of Infection and Infectious Diseases in People, in case of occurrence of the state of epidemic or the state of epidemiological threat of a character and on the scale exceeding the potential of competent governmental and local administration bodies, the Council of Ministers may define, in the form of a regulation, pursuant to the data conveyed by the Minister of Health, Minister of Public Administration, Head of Sanitary Inspection, and voivodes: 1) the area at risk, along with the indication of a kind of zone on which the state of epidemic or the state of epidemiological threat occurred, 2) a kind of applied solutions - in a scope defined in Article 46(b) - having in mind a range of applied solutions and taking into account current possibilities of the state budget and budgets of local administration bodies. Pursuant to Article 46(b) of the Act on the Prevention and Combating Infection and Infectious Diseases in People, in the discussed regulation of the Council of Ministers the following can be specified: 1) restrictions, duties, and orders, the same which can be established by a voivode and the Minister of Health 2 ) temporary restriction of defined ranges of business activity; 3) temporary rationing of specific kinds of products; 4) a duty to undergo medical examination by persons who are sick or suspected to be sick; 5) a duty to use specific preventive measures and procedures; 6) a duty to subject oneself to quarantine; 7) place of quarantine; 8) (derogated); 9) temporary restriction of using premises or territories as well as a duty to secure them; 10) an order of evacuation in the specified time from defined places, territories, 
and premises; 11) an order or prohibition to stay in defined places and premises and on specified areas; 12) prohibition of leaving the zone zero by persons who are sick or suspected to be sick; 13) prohibition of a specified way of social mobility, 14) an order to cover mouth and nose in specified circumstances, places and premises and in defined areas, together with a method to implement this order.

The contents of Article 46(a) of the Act on the Prevention and Combating Infection and Infectious Diseases in People elicit simple associations with a state of necessity, which, however, this act of law completely distances itself from, since it is just meant to provide an unconstitutional "remedy" for the failure on the part of the Council of Ministers to apply measures contained in the Act on Natural Disasters. Another issue, however, exceeding the scope of this article, is a fact that the regulations issued pursuant to Article 46(4), Article 46(a), Article 46(b) of the Act on the Prevention and Combating Infection and Infectious Diseases in People exceeded in its regulations beyond the limits of delegation of statutory power. ${ }^{25}$

\section{FINAL CONCLUSIONS}

Taking a stance to the presented regulation it should be stated that pursuant to the explicit provisions of the Constitution the two-stage legislation is allowed (act of law and regulation of the Council of Ministers) relating to the introduction of the legal state of natural disaster, which is a special and exceptional regime of law. However, such a two-stage regulation provided for by an ordinary act of law, like it was provided for in the Act on the Prevention and Combating Infection and Infectious Diseases in People, is not constitutional, which is not issued concurrently with the introduction of the state of natural disaster, with full justification and legal impact which the Constitution connects with the legal notion of the state of natural disaster. Metaphorically speaking, it can be stated that in this case the legislature, using phrases which were merely "buzzwords", such as the "state of epidemiological threat" and "state of epidemic", respectively, linked to them the legislative powers belonging to public administration bodies, which resembled in their construction the solutions found in the Act on the State of Natural Disaster. ${ }^{26}$ However, the legislature avoided - owing to using only the two above terms and alienating from the special legal regime of the state of natural disaster, such as the legal impact which was presented above, which the Constitution links with the constitutional legal notion of the state of natural disaster. ${ }^{27}$ Ordinary legislature, in the Act on the Prevention and Combating the "State of Epidemic", introduces the competitive "state of epidemic threat" and the "state of epidemic", respectively, as special legal regimes, failing to adhere to the principles which the Constitution connects with

25 See FLORCZAK-WATTOR, c. d., p. 13.

26 Compare KURZĘPA, E. Stan epidemii a stan klęski żywiołowej - rozważania w kontekście bezpieczeństwa państwa. Przegląd Prawa Publicznego. 2021, No. 5, pp. 8-9.

27 These regulations were added by Art. 25 item 4 of the Act of 2 March 2020 on special solutions connected with prevention, counteraction and combating of COVID-19, other infectious diseases and related crisis situations, Dz.U. - Journal of Laws - 374. 
the states of exception, including the state of natural disaster, so therefore not finding any foundation for the above actions in the Constitution.

In this a normative system, which has to be defined as unconstitutional, the first law-making stage was, inter alia, the review of the Act of 05 December 2008 on the Prevention and Combating of Infection and Infectious Diseases in People, ${ }^{28}$ and the other stage being the introduction of "the state of epidemiological threat" and "the state of epidemic", respectively, in a form of regulations issued by competent bodies, in order to avoid the legal possibilities and effects arising from the Act on the State of Natural Disaster, so therefore the introduction of the state of natural disaster. In this situation this normative system will be analysed with a view to constitutionality with Article 31 of the Constitution of the Republic of Poland. Here it has to be stated that if the ordinary legislature revising the Act of 05 December 2008 on the Prevention and Combating Infection and Infectious Conditions in People did not consider the state of epidemic and the state of epidemiological threat as an equivalent of the state of natural disaster - then it is not understandable why from the perspective of the Constitution the legislature linked the epidemic and the epidemiological threat with the law-making potential of public administration bodies, which the Constitution does not provide for in ordinary constitutional measures. Nothing precluded the introduction of amendments (if any) to the state on natural disaster management act prior to the introduction of the state of natural disaster ${ }^{29}$ and the systemic operation of the public bodies pursuant to, inter alia, three acts: Act on the State of Natural Disaster and the Act on Prevention and Management of Infection and Infectious Diseases in People, as well as of the Act of 02 March 2020 on special solutions connected with prevention, counteraction and fighting COVID-19, other infectious diseases and the crisis situations evoked by them. "Escape" from the solutions of the Act on the State of Natural Disaster both on the side of the legislature as well as on the side of public administration implementing the law, most probably had a political dimension also, since the introduction of the legal state of natural disaster generates disaster-related restrictions and issues of liability for damages on the side of the state for the so-called legal damages. ${ }^{30}$ Here a question arises on the justifiability of existence in the constitutional legal order of the regulation regarding the states of exception, including the state of natural disaster, if the legislature, disregarding all the prerequisites of factual circumstances and the existing constitutional legal order introduces non-constitutional regulations which by definition "compete" with the Constitution and the Act on the state of natural disasters.

In a mood of a sad reflection, it must be concluded that against the obligation of acting in due time, the Council of Ministers did not exercise the rights which the Act on the State of Natural Disaster provides for. Just as it has been explained in the introduction, even discretionary competences, which award a certain margin of freedom in

28 See TULEJA, $c . d$.

29 See BOĆ, J. Wyrównanie strat wynikłych z legalnych działań administracji. Wrocław: Zakład Narodowy im. Ossolińskich, 1971.

30 See PECYNA, M. Odpowiedzialność odszkodowawcza Skarbu Państwa za ograniczenia praw i wolności w czasie epidemii COVID-19. Państwo i Prawo. 2020, No. 12, pp. 23-37. 
decision making, in reality of prerequisites meeting the hypothesis of a norm, including unmarked notions which the norm uses - become a subject of an affirmative duty.

The raised issue of unconstitutionality of restricting human and civil rights and freedoms, as well as of other entities opens another discussion regarding the liability for damages of the State Treasury for illegal restrictions of rights and freedoms during the COVID-19 epidemic outbreak in relation to Article 77 of the Constitution and Article 417 [1] § 1 of the civil code.

prof. dr hab. Iwona Niżnik Dobosz

Faculty of Law and Administration, Jagiellonian University in Kraków

iwona.niznik-dobosz@uj.edu.pl 